\title{
Pendidikan Lingkungan: Plastic Pollution Awareness di Desa Jatireja, Cikarang, Jawa Barat
}

\author{
${ }^{1)}$ Filson M Sidjabat, ${ }^{2)}$ Yunita Ismail, ${ }^{3)}$ Evi Rismauli \\ 1), 2) Fakultas Teknik, Universitas Presiden \\ 3) Fakultas Bisnis, Universitas Presiden \\ 1) fmsidjabat@president.ac.id \\ 2) yunitaismail@president.ac.id \\ 3) evi@president.ac.id
}

\begin{abstract}
ABSTRAK
Permasalahan sampah di Indonesia mengalami titik kritis yang mencemari berbagai aspek di tengah masyarakat. Pengelolaan sampah di daratan yang tidak baik, berimbas pada pencemaran badan air, sungai, yang bermuara ke lautan. Pencemaran badan sungai dan lautan oleh sampah ini menjadi sorotan dunia dan pemerintah pusat. Sebagai bagian dari komunitas pendidikan di Jawa Barat, Universitas Presiden memiliki peran dalam mengedukasi dan mencari solusi terkait permasalahan ini, salah satunya dengan menjalankan tridharma dalam bentuk kegiatan pengabdian masyarakat di Desa Jatireja. Kegiatan pendidikan lingkungan ini berupa penyuluhan yang memberikan wawasan terkait sampah plastik, pengolahan dan pengelolaan yang bisa dilakukan dalam skala rumah tangga, dan mendorong perubahan perilaku dan kepedulian masyarakat terhadap permasalahan ini. Sosialisasi kreasi kreatif bata plastik (ecobrick) juga diterapkan sebagai usaha pemanfaatan sampah menjadi produk bernilai guna. Kegiatan pendidikan lingkungan ini perlu terus dilakukan dan ditingkatkan agar kesadaran dan kepedulian akan sampah plastik ini meningkat di tengah masyarakat Indonesia, khususnya Jawa Barat.
\end{abstract}

Kata-kata Kunci: Sampah Plastik, Kepedulian Masyarakat, Pengelolaan Sampah,

Pendidikan Lingkungan

\begin{abstract}
Waste problems in Indonesia has reached a critical point that is contaminating many aspects in community. Poor waste management in land have an impact in water pollutions, rivers, and toward the ocean. This rivers and oceans pollution are become the spotlights for the world and the government. As a part of education community in West Java, President University has an important role to educati and find solutions relate with this issues, one of them is to implement Thidharma in the form of social empowerment in Jatireja Village. This environmental education activities was sharing knowledge about plastic waste treatment and management that can be conducted in household scale, and to encourage behavioral change and awareness among communities. Creative product of ecobrick was also implemented tas a part of waste utilization to make valueable product. Environmental education are needed to improve community awareness on plastic waste in Indonesia, especially in West Java.
\end{abstract}

Keywords: Plastic Waste, Community Awareness, Waste Management, Environmental Education

\section{PENDAHULUAN}

Permasalahan sampah di Indonesia mengalami titik kritis yang mencemari berbagai aspek di tengah masyarakat. Data Kementerian Lingkungan Hidup dan Kehutanan mencatat, Indonesia memproduksi 65 juta ton sampah pada 2016, naik 1 juta ton dari tahun sebelumnya. Permasalahan sampah yang tidak terkelola dengan baik di daratan, berdampak pada pencemaran badan air, yang juga bermuara ke laut. Indonesia dinyatakan sebagai pencemar sampah ke lautan kedua terbesar menurut penelitian di tahun 2015 oleh 
Jambeck, Geyer, Wilcox, Siegler, Perryman, Andrady, Narayan, and Law (2015). Pencemaran badan air, seperti pada Sungai Citarum, di Jawa Barat, menjadi sorotan dunia dan pemerintah pusat saat ini.

Sungai Citarum digunakan masyarakat sepanjang daerah aliran sungai (DAS), untuk konsumsi air bersih, budidaya ikan, irigasi, dan pasokan listrik. Kondisi sekarang telah tercemar parah oleh beragam limbah, dari industry, dari medis (limbah medis), dan sampah (lihat Gambar 1 - 2). Kualitas air Citarum rusak parah, terdapat data berikut: tinja manusia 35.5 ton/hari, tinja hewan 56 ton/hari, sampah 20.462 ton/hari, limbah industri 340.000 ton/hari, dan limbah medis yang tidak diketahui. Sampah organik \& anorganik $71 \%$ tidak terangkut, dan bercampur dengan banyak limbah medis. Kondisi ini diperparah dengan adanya 1.900 Industri dan 90\% tidak memiliki IPAL. Industri yang berkembang di sepanjang DAS Citarum ini cenderung karena memiliki kemudahan sumber air bersih, dan kemudahan membuang limbah. Sekitar 80.000 keramba jaring apung yang melebihi beban 3 waduk, menghasilkan pendangkalan dan debit air berkurang (sedimentasi), turbin PLTA yang rusak karena banyak sampah, dan ikan tercemar yang dikonsumsi masyarakat (DKN, 2018). Permasalahan di Sungai Citarum adalah satu dari permasalahan sampah yang tidak dikelola dengan baik.

Permasalahan lainnya akibat sampah plastik yang masuk badan air dan lautan adalah adanya mikroplastik pada setiap sumber daya alam dari lautan, seperti garam. Lebih dari 90\% merek garam yang disampel secara global ditemukan mengandung mikroplastik, di mana jumlah tertinggi berasal dari sampel garam yang bersumber di Asia, menurut sebuah penelitian baru yang dirancang bersama oleh Seung-Kyu Kim, Profesor di Universitas Incheon dan Greenpeace Asia Timur (Kim, Jisu, 2018). Mikroplastik yang masuk ke wilayah perairan melalui saluran limbah rumah tangga, umumnya mencakup polietilen, polipropilen, dan polistiren. Sumber sekunder meliputi serat atau potongan hasil pemutusan rantai dari plastik yang lebih besar yang mungkin terjadi sebelum mikroplastik memasuki lingkungan. Potongan ini dapat berasal dari jala ikan, bahan baku industri, alat rumah tangga, kantong plastik yang memang dirancang untuk terdegradasi di lingkungan, serat sintetis dari pencucian pakaian, atau akibat pelapukan produk plastik (Browne, Crump, Niven, Teuten, Tonkin, Galloway, \& Thompson, 2011). Masalah mikroplastik dan pencemaran lautan ini tidak hanya berdampak pada kesehatan manusia, utamanya hal ini merusak rantai makanan dan seluruh biota di lautan, salah satu contoh di Wakatobi, Papua. Pada Minggu (18/11/2019) Laude M. Saleh Hanan, volunteer Yayasan Wakatobi, yang juga menjadi Ketua Badan Promosi Wakatobi, bersama dengan WWF dan Akademi Komunitas Perikanan dan Kelautan (AKKP) Wakatobi menemukan Paus Sperma ( $P$. Macrocephalus) yang sudah menjadi bangkai di perairan Desa Kapota, Kecamatan Wangi Wangi Selatan, Kabupaten Wakatobi, Sulawesi Tenggara. Saat melakukan pemeriksaan terhadap organ dalam paus 
tersebut, berbagai sampah ditemukan. Dari hasil identifikasi yang dilakukan dosen AKKP Wakatobi, ditemukan beberapa jenis sampah plastik dengan komposisi: gelas plastik 750 gram (115 buah), plastik keras 140 gra, (19 buah), botol plastik 150 gram (4 buah), kantong plastik 260 gram (25 buah), serpihan kayu 740 gram (6 potong), sandal jepit 270 gram (2 buah), karung nilon 200 gram (1 potong), tali rafia 3260 gram (lebih dari 1000 potong), di dalam tubuh paus. Secara total, berat basah sampah yang dimakan hewan malang tersebut berjumlah 5,9 kilogram. Ini bukanlah angka yang sedikit. Apalagi, sebagian besar sampah tadi telah berubah warna. Hal ini menandakan bahwa sampah-sampah tersebut sudah berada di dalam tubuh paus ini dan mengendap dalam waktu yang lama (Sedayu, 2018 dan Widyaningrum, 2018). Permasalahan pencemaran sampah di badan air dan lautan ini harus menjadi perhatian berbagai instansi termasuk pendidikan, dan berkontribusi dalam berbagai skala, khususnya skala lokal.

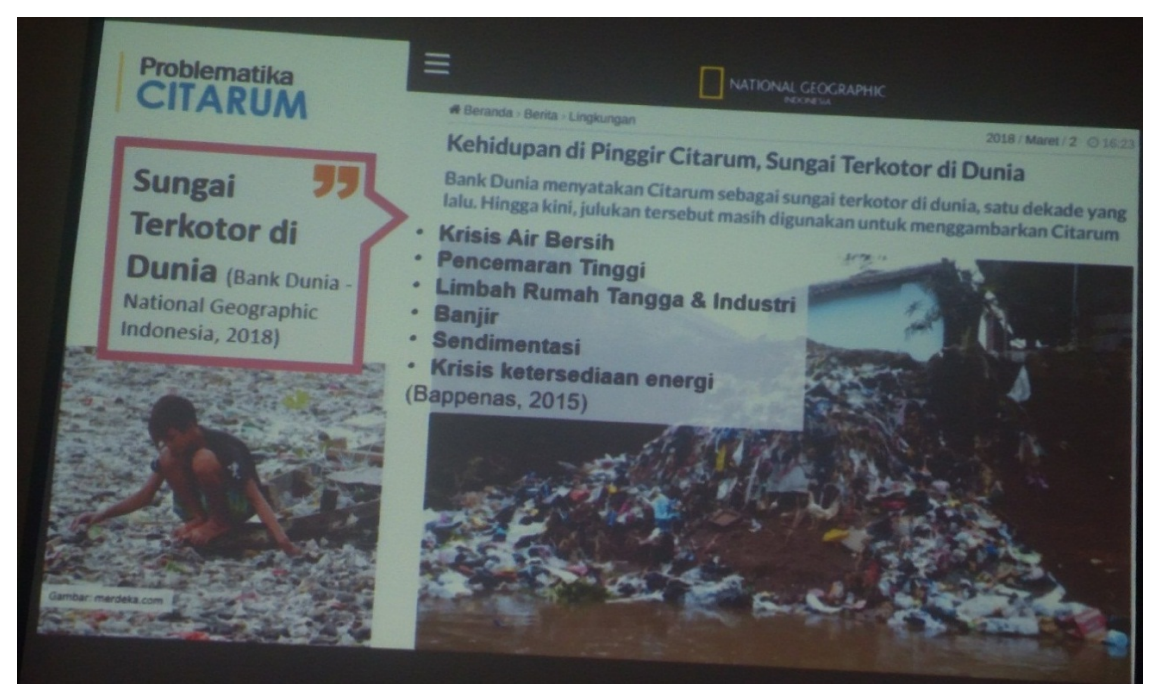

Sumber: DKN, 2018

Gambar 1. Kondisi Permasalahan Citarum Saat Ini 


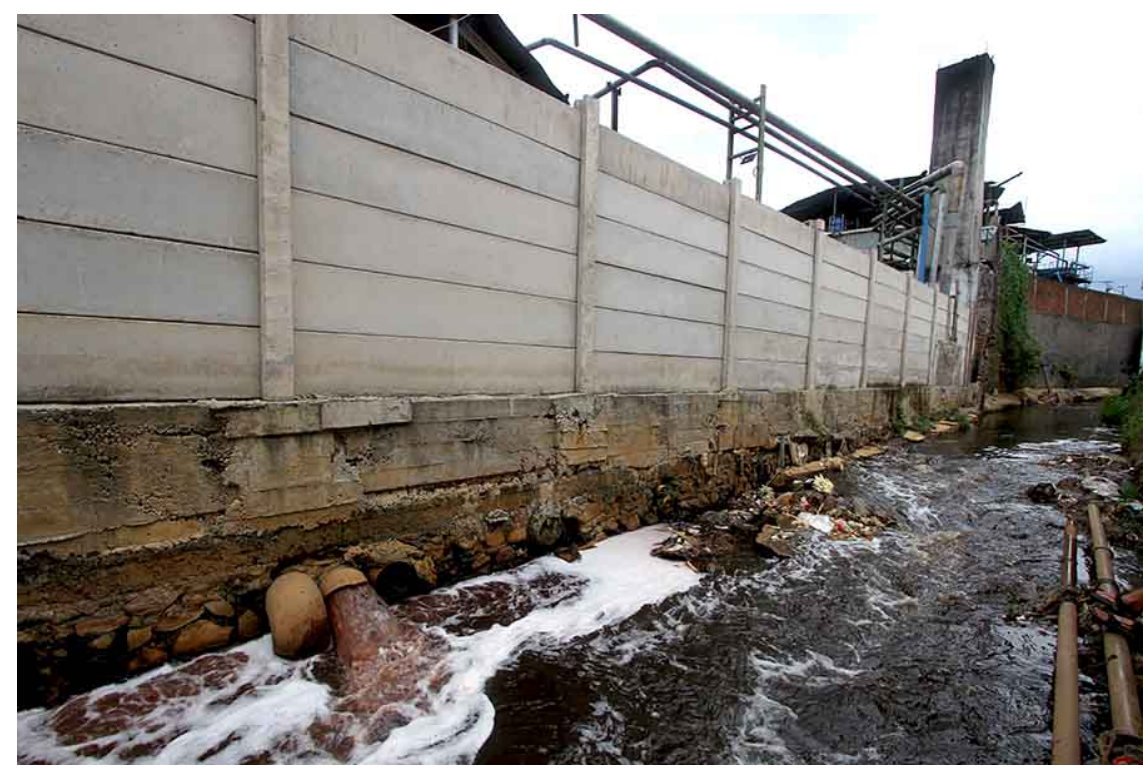

Gambar 2.

Pembuangan limbah langsung ke Sungai Citarum di Majalaya, Kabupaten Bandung.

(Sumber Foto: Donny Iqbal/Mongabay Indonesia)

Sebagai tanggapan perguruan tinggi dalam permasalahan ini, diperlukan keterlibatan lembaga pendidikan tinggi dalam restorasi DAS Citarum. Sesuai dengan tridharma pendidikan, beberapa hal yang bisa dilakukan oleh Perguruan Tinggi, diantaranya berupa pendidikan lingkungan. Pemahaman terhadap permasalahan lingkungan di Kota Bandung dan Citarum Hulu dan kesadaran lingkungan dalam sikap dan tingkah laku terhadap air dan sampah perlu ditingkatkan. Dalam pendidikan, perlu juga dilakukan inovasi pembelajaran: kerja kelompok, observasi, kajian pustaka, juga kuliah kerja nyata tematik, seperti: pendidikan karakter melalui pengalaman nyata di lapangan dan kerja bersama masyarakat mengatasi masalah lingkungan. Atas dasar tersebut perlu ditingkatkan pendidikan lingkungan terkait permasalahan sampah plastik di Indonesia ini, di berbagai golongan masyarakat. Untuk itu, dilaksanakan pengabdian kepada masyarakat dalam bentuk pendidikan lingkungan dengan tema: Plastic Pollution Awareness. Tujuan dari PKM ini adalah: (1) Untuk pendidikan lingkungan guna meningkatkan kesadaran dan kepedulian terhadap permasalahan sampah plastik; khususnya di Provinsi Jawa Barat (2) Membuat berbagai kreasi, termasuk panduan ataupun materi penyuluhan yang dapat dimultiplikasi oleh berbagai golongan masyarakat.

\section{METODE PELAKSANAAN}

Metode yang akan digunakan dalam kegiatan pengabdian masyarakat ini adalah dengan penyuluhan kepada masyarakat, dengan memberikan wawasan terkait sampah plastik, bagaimana pengolahan dan pengelolaan yang bisa dilakukan dalam skala rumah tangga, bagaimana agar mau merubah perilaku dan peduli terhadap permasalahan plastik 
ini. Penyuluhan juga mengumpulkan dan mensosialisasikan kreasi kreatif dari berbagai daerah di Indonesia, dengan menggunakan berbagai jenis sampah, dimanfaatkan menjadi produk yang bernilai guna.

Kegiatan pengabdian masyarakat ini terdiri dari 2 kegiatan untuk menjawab dua tujuan yang telah ditetapkan.

\subsection{Kegiatan 1: Pendidikan Lingkungan - Penyuluhan Pemilahan Sampah}

Kegiatan penyuluhan ini bertujuan untuk meningkatkan kesadaran lingkungan terutama sampah plastik yang membuat masyarakat menyadari pentingnya pengurangan penggunaan sampah plastik, pemilahan sampah, dan pemanfaatannya. Masyarakat dapat memanfaatkan sampah plastik menjadi barang yang dapat digunakan kembali, salah satunya adalah dengan menjadikan bata plastik (ecobrick).

\subsection{Kegiatan 2: Pemanfaatan Sampah Plastik - Kreasi Bata Plastik (Ecobrick)}

Kegiatan pemanfatan sampah plastik ini bertujuan untuk meningkatkan kesadaran masyarakat untuk sampah plastik residu yang sudah tidak bernilai ekonomis, dikumpulkan ke dalam botol plastik yang dapat dibentuk menjadi kreasi seperti tempat duduk, meja, panggung, pengganti bata untuk bangunan non-permanen. Kreasi ini juga mengingatkan setiap orang yang melihatnya agar dapat mengurangi penggunaan plastik sekali pakai sebagai bentuk kepedulian terhadap permasalahan lingkungan saat ini.

\subsection{Penentuan Lokasi: Desa Jatireja, Cikarang Timur.}

Kegiatan penyuluhan ini ditujukan kepada penduduk yang bertempat tinggal di RT 03 RW 05 Desa Jatireja, Kecamatan Cikarang Timur, Kabupaten Bekasi, Jawa Barat. Penduduk di desa tersebut menggunakan air sungai kecil sebagai sumber utama kehidupan mereka, seperti mencuci, mandi, dan kegiatan rumah tangga lainnya. Namun, seiring berjalannya waktu banyak sampah yang terbawa ke sungai tersebut dan mengakibatkan sumber air tercemar oleh sampah. Permasalahan sampah di Desa Jatireja antara lain, tidak tersedianya tempat pembuangan sampah (tempat sampah) di setiap rumah dan tidak adanya pengambilan sampah rutin dari Dinas Kebersihan dan Pertamanan Kabupaten Bekasi. Hal ini membuat masyarakat melakukan pembakaran sampah setiap sore hari dikarenakan permasalahan tersebut dan kurangnya pengetahuan masyarakat tentang persampahan. 

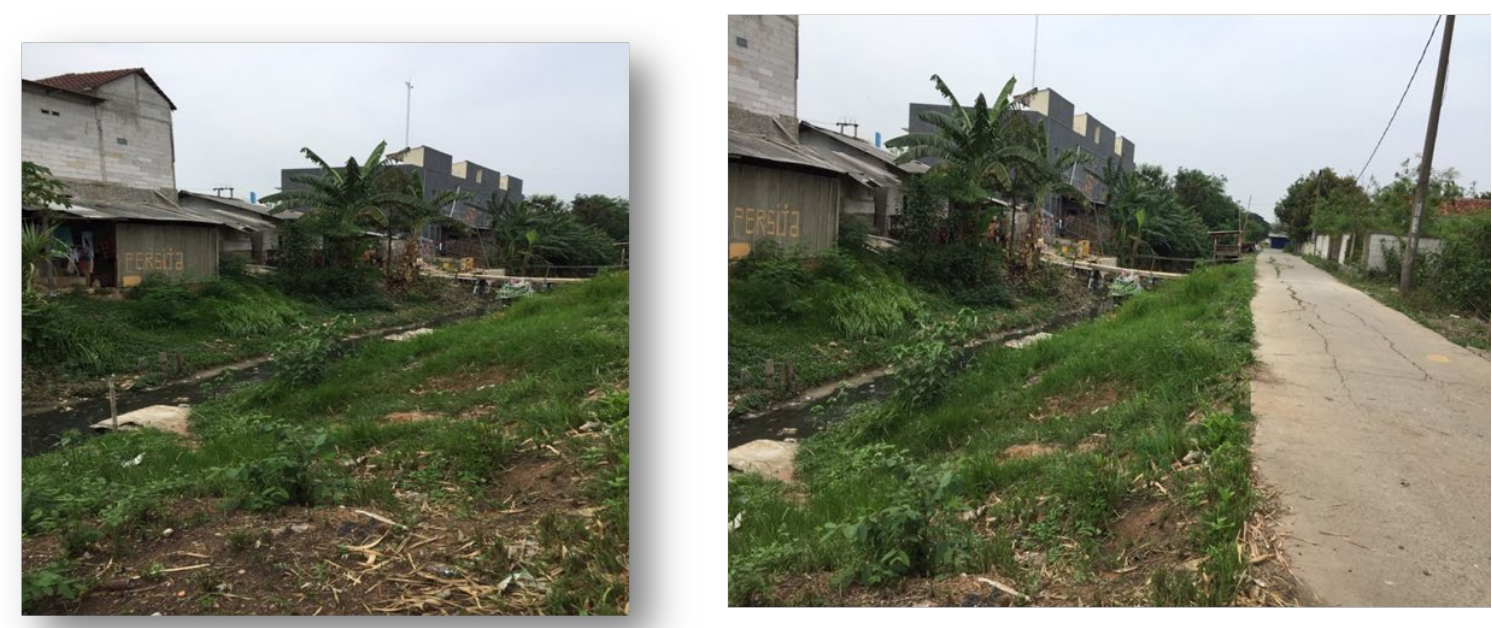

Gambar 3. Kondisi Lingkungan Desa Jatireja (Sumber Foto: Hasil Survei Tim)

\section{HASIL DAN PEMBAHASAN}

\subsection{Hasil Kuesioner sebelum Penyuluhan}

Dari 28 responden dapat dilihat bahwa tingkat pendapatan dari 22 respon berada pada pendapatan dibawah Rp.3.000.000,- / bulan (lihat Gambar 4). Umumnya penduduk berprofesi ]sebagai pegawai pabrik, usaha mikro, supir truk, dan di klinik kesehatan.

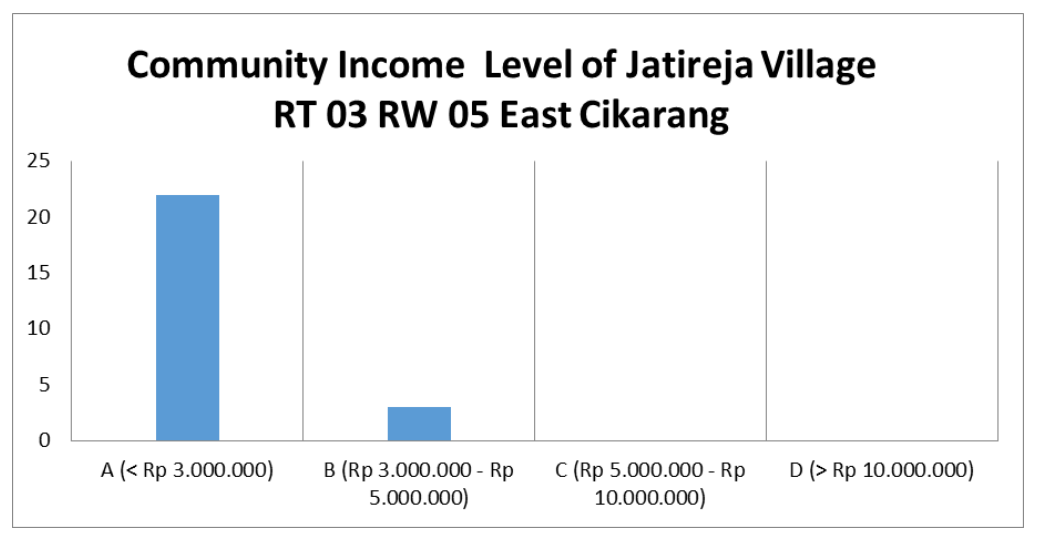

Gambar 4. Tingkat Pendapatan Penduduk Desa Jatireja

Penduduk Desa Jatireja juga memiliki perhatian tentang kebersihan lingkungan di sekitar rumah (lihat Gambar 5). 12 responden peduli akan permasalahan sampah, 8 responden terhadap kebersihan air dan sampah, 1 responden terhadap air limbah domestik yang dihasilkan dari kegiatan sehari-hari. Secara umum, di sekitar Desa Jatireja tidak ada pengumpulan dan pemilahan sampah secara rutin. Dilakukan pembuangan sampah sembarangan dan pembakaran sampah, dikarenakan tidak adanya jadwal pengambilan sampah dari Dinas LH Kabupaten, ataupun dari pihak lain. Air limbah domestik juga dibuang langsung ke sungai. Ini menimbulkan sanitasi yang rusak yang dapat berpotensi 
mengancam kesehatan penduduk Desa Jatireja (lihat Gambar 6). Pada Gambar 6, responden menjawab pertanyaan berikut: "Pernahkah Anak atau Bapak/lbu mengalami penyakit seperti diare, demam berdarah, infeksi/penyakit kulit, tifus, cacingan? Apa saja penyakit yang pernah dialami? Seberapa sering dalam 1 tahun penyakit tersebut dialami? “. Jawaban dari pertanyaan berikut menunjukkan 4 responden menyatakan menderita penyakit kulit, 2 responden menderita tipes, 6 responden menderita diare, 3 responden menderita gejala demam, dan 1 responden menderita cacingan, dengan frekuensi kejadian $1-5$ kejadian tiap tahun.

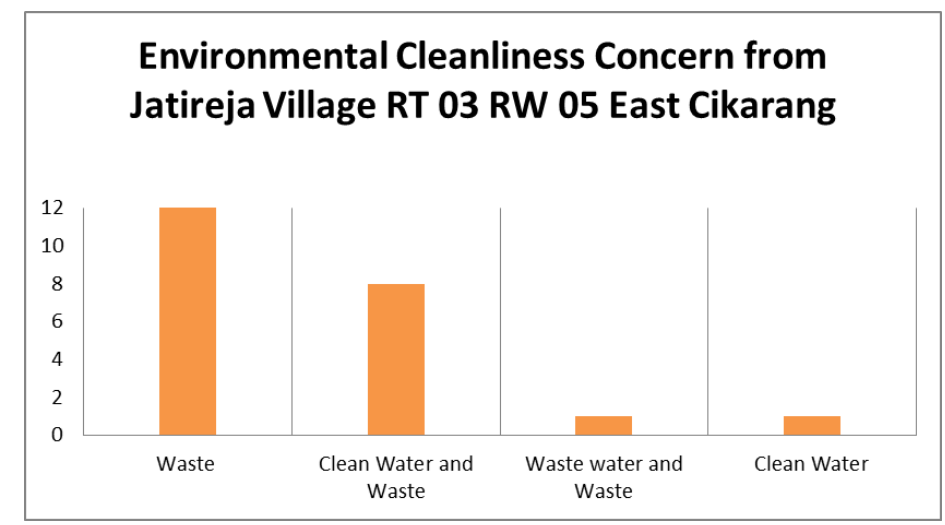

Gambar 5. Prioritas Perhatian terhadap Kebersihan Lingkungan di sekitar Desa Jatireja

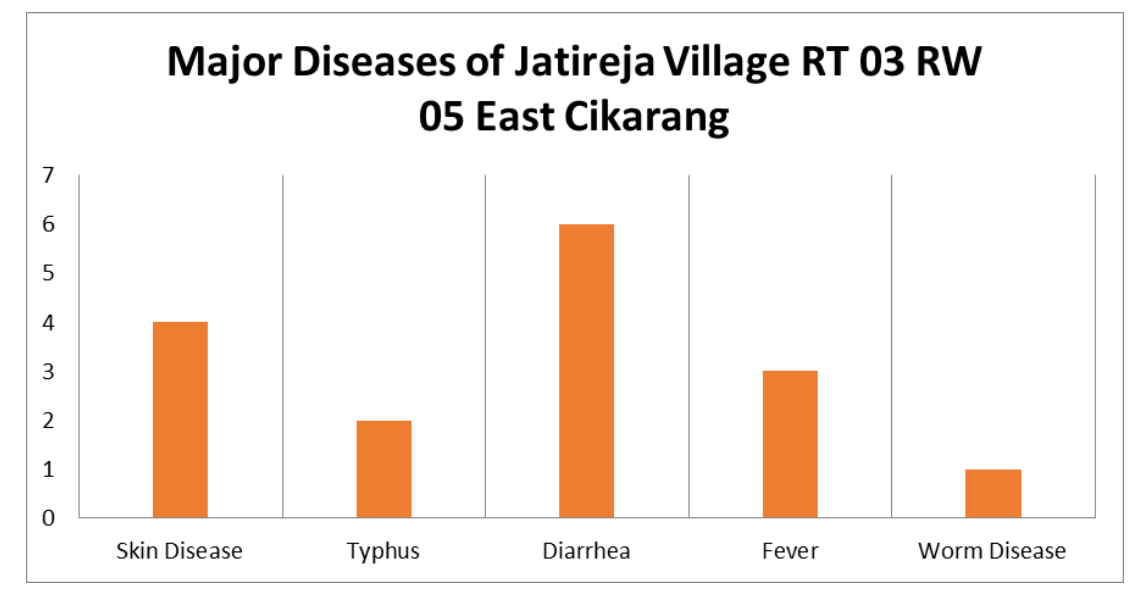

Gambar 6. Penyakit yang sering dialami oleh anggota Keluarga Penduduk Desa Jatireja

Sebelum kegiatan penyuluhan diberikan, kuesioner ini dibagikan sebagai latar belakang data responden peserta penyuluhan. Pada Gambar 7, 13 responden dari 28 total menyatakan belum mengetahui bagaimana pengelolaan sampah rumah tangga yang baik. Walaupun demikian, seluruh peserta penyuluhan memiliki keinginan yang kuat untuk berpartisipasi dalam kegiatan sanitasi untuk lingkungan sekitar yang lebih baik (lihat Gambar 7 bagian kanan). 


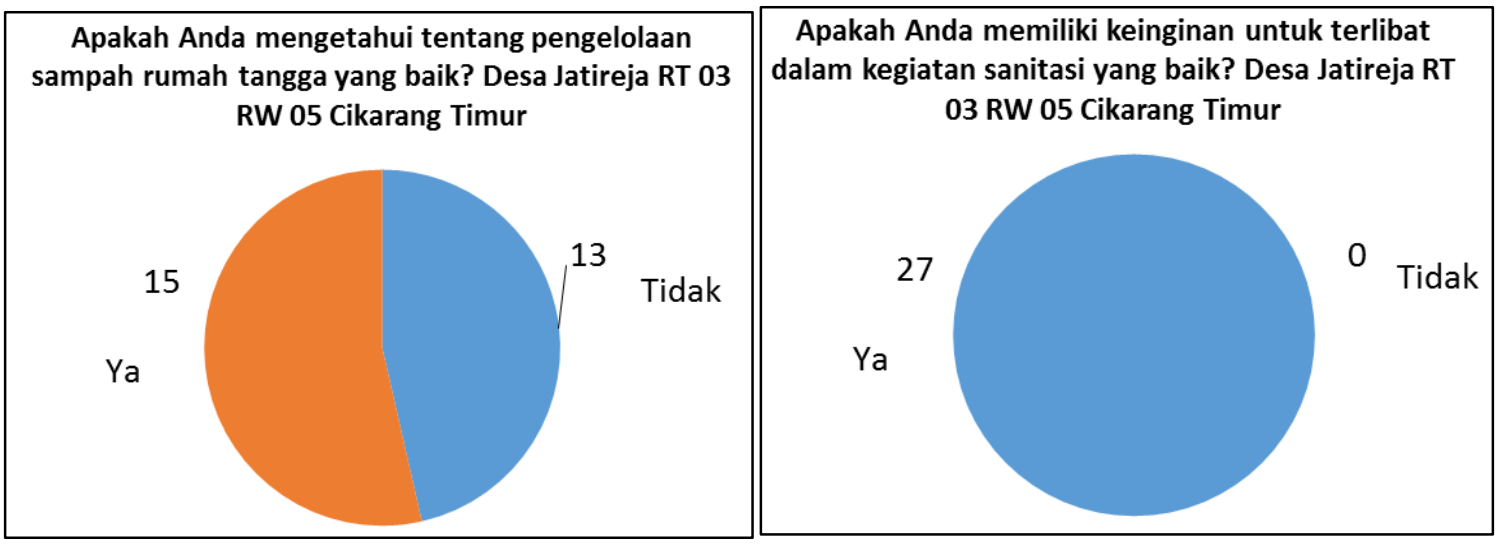

Gambar 7. Pengetahuan akan Pengelolaan Sampah dan Tingkat Partisipasi

Keterlibatan penduduk Desa Jatireja dalam pengelolaan sampah, sanitasi dan kebersihan lingkungan yang dapat dan ingin dilakukan adalah mengumpulkan sampah yang bernilai jual/dapat digunakan kembali (21 responden), pemilahan sampah yang baik (3 responden), dan 2 responden yang menyatakan tidak bersedia berpartisipasi (lihat Gambar 8).

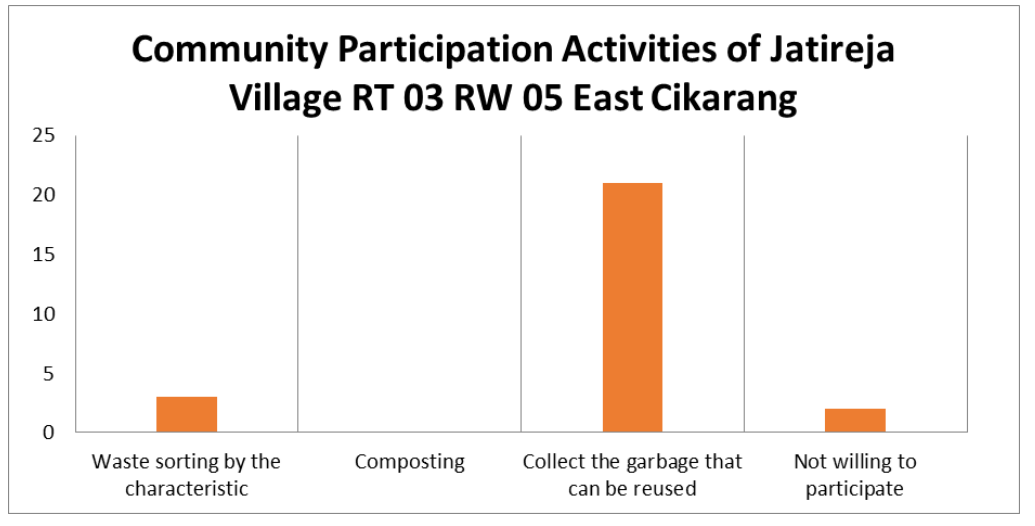

Gambar 8. Keterlibatan Kegiatan Kebersihan Lingkungan Penduduk Desa Jatireja

\subsection{Kegiatan Penyuluhan Pemilahan Sampah}

Secara umum, masyarakat yang sudah mengetahui mengenai konsep $3 R$ yaitu Reduce, Reuse, Recycle (Mengurangi, menggunakan kembali, mendaur ulang). Kemudian dikenal juga konsep baru yaitu $5 R$ (Refuse, Reduce, Recycle, Replace, Repair). Namun, seiring dengan berkembangnya zaman, muncul konsep baru yang lebih inovatif dalam pengelolaan sampah plastik, yaitu $7 R$ (Reduce, Replace, Reuse, Recycle, Recover, Refuse and Reject, Rethink) (Abella, 2013).

Salah satu konsep yang dibahas dalam penyuluhan ini adalah terkait Reduce, Replace, Reuse, dan Recycle. Dalam pengelolaannya, setiap konsep ini tidak lepas dari usaha memilah sampah dari sumber. Sampah yang terpilah akan lebih mudah untuk 
digunakan kembali/dibentuk untuk tujuan lainnya, juga memiliki nilai ekonomis yang lebih baik.

Dari kegiatan penyuluhan ini, dirasakan bahwa penduduk Desa Jatireja begitu antusias dalam kegiatan penyuluhan, dan kegiatan memungut sampah di sekitar lingkungannya (lihat Gambar 9). Keaktifan dan keterlibatan mahasiswa dalam kegiatan penyuluhan ini memberikan kesan yang baik, yang memberikan contoh untuk penduduk Desa Jatireja lebih bijak dalam melakukan pemilahan sampah, dan dalam menggunakan sampah plastik. Pemberian tong sampah dengan beragam jenis juga dilakukan agar keberlanjutan dari penyuluhan pemilahan sampah ini terus diterapkan di Desa Jatireja. Poster yang dibuat dalam kegiatan penyuluhan ini juga sebagai sumbangsih terhadap masyarakat untuk meneruskan materi edukasi ini diberbagai kesempatan lainnya (lihat Gambar 10).

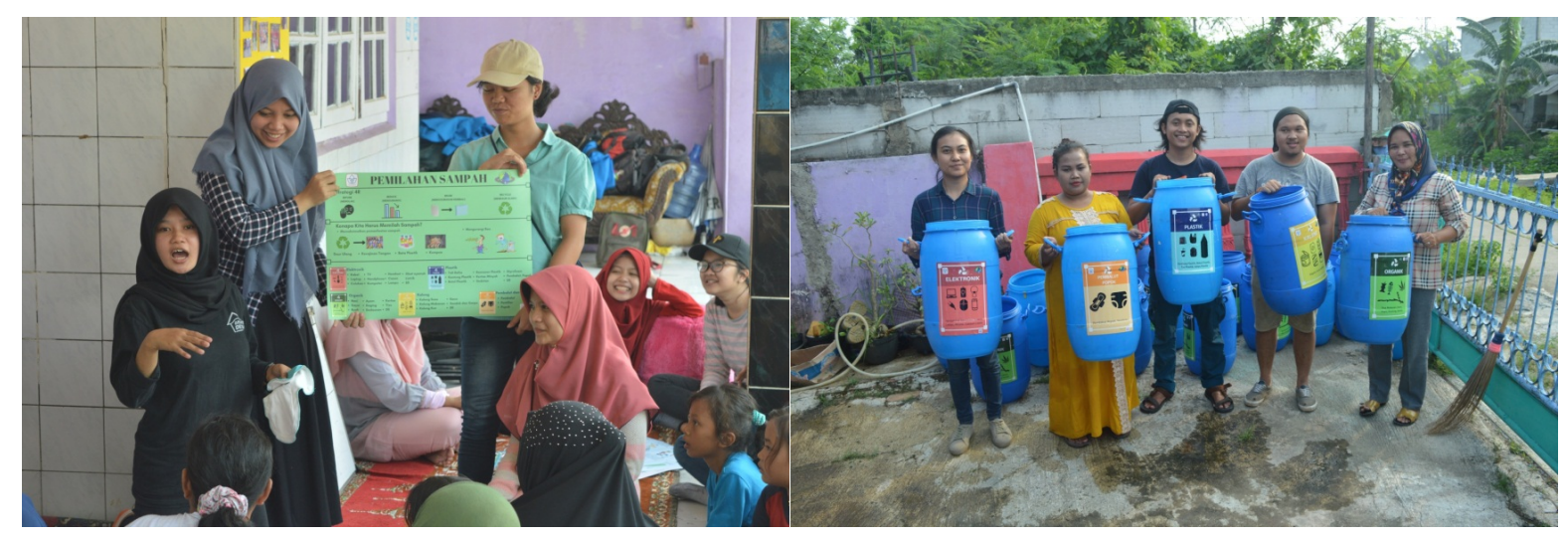

Gambar 9. Kegiatan Penyuluhan Pemilahan Sampah dan Pemberian Tong Sampah (sesuai jenis pemilahannya) 


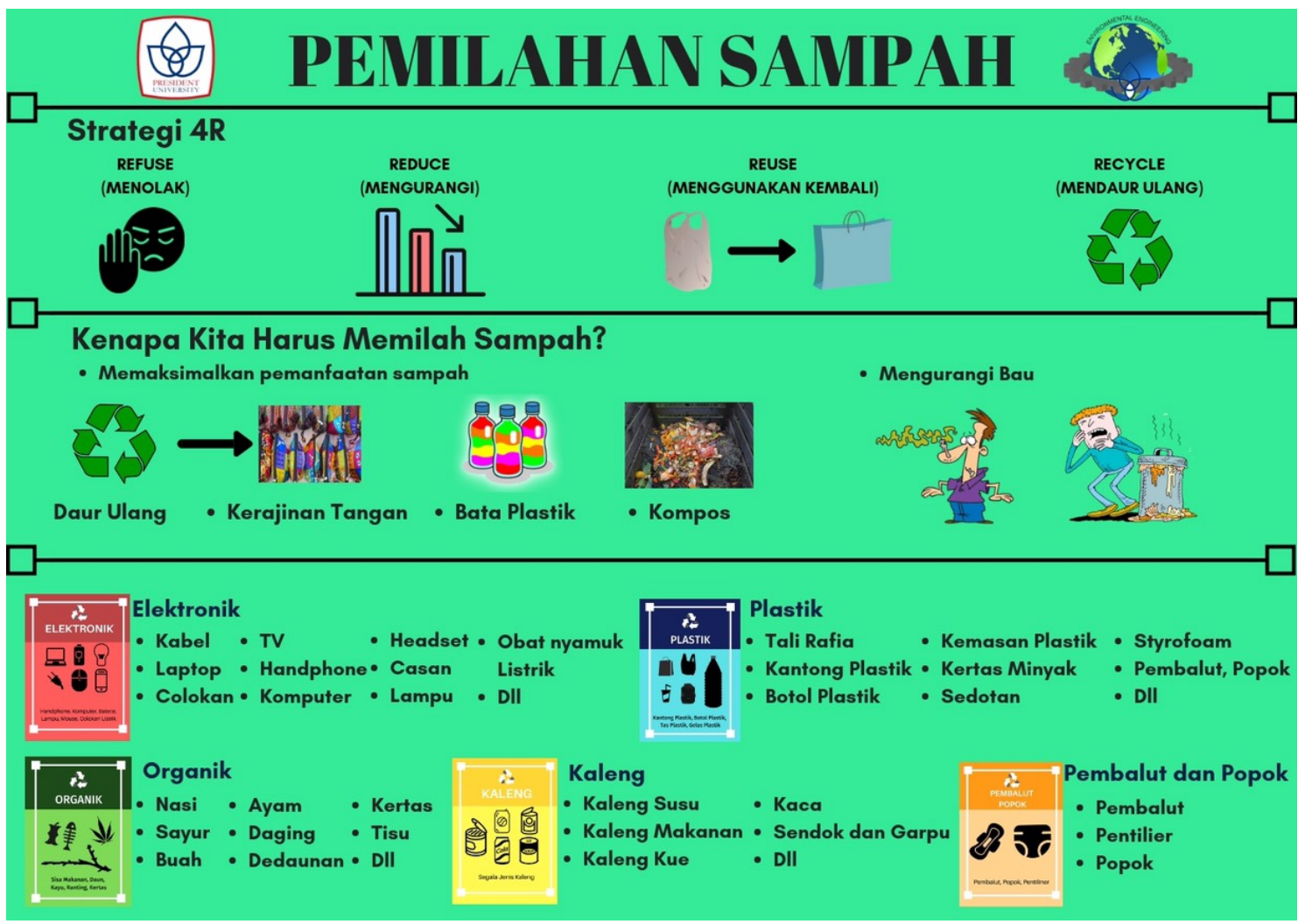

Gambar 10. Poster Materi Penyuluhan - Pemilahan Sampah

Upaya mengurangi sampah plastik harus dimulai dari lingkup masyarakat. Namun, salah satu tantangan terbesar dalam mengurangi sampah plastik adalah kesadaran dan kepedulian masyarakat akan masalah yang timbul akibat sampah plastik. Berbagai penolakan dari masyarakat terhadap edukasi dan komunikasi mengenai sampah plastik mempersulit para aktivis lingkungan untuk mengajak masyarakat peduli akan sampah plastik. Oleh karena itu, diperlukan ilmu komunikasi lingkungan, yaitu adalah cabang ilmu komunikasi yang ditujukan untuk membahas hal hal seputar lingkungan. Selain itu juga diperlukan strategi komunikasi yang baik supaya masyarakat dapat mengerti dan ikut tergerak untuk peduli dengan masalah yang timbul akibat sampah plastik, contohnya seperti melakukan kampanye mengenai sampah plastik, lokakarya, seminar, dan sebagainya (Kurniadi \& Hizasalasi, 2017 dan Ismail \& Sidjabat, 2019).

\subsection{Kegiatan Pemanfaatan Sampah - Kreasi Bata Plastik}

Saat ini, ada banyak inovasi yang dikembangkan dalam upaya pengelolaan sampah plastik. Inovasi yang paling sering ditemukan adalah dalam proses daur ulang. Daur ulang plastik memiliki keunggulan di berbagai aspek, seperti efektivitas, ekonomis, dan mudah. Dengan mendaur ulang plastik menjadi barang baru, dapat memberikan manfaat terhadap lingkungan dan ekonomi pendaur ulangnya. Saat ini, sangat banyak ide -ide untuk mendaur 
ulang sampah plastik, seperti membuatnya menjadi kerajinan tangan dan ecobrick (lihat Gambar 11).

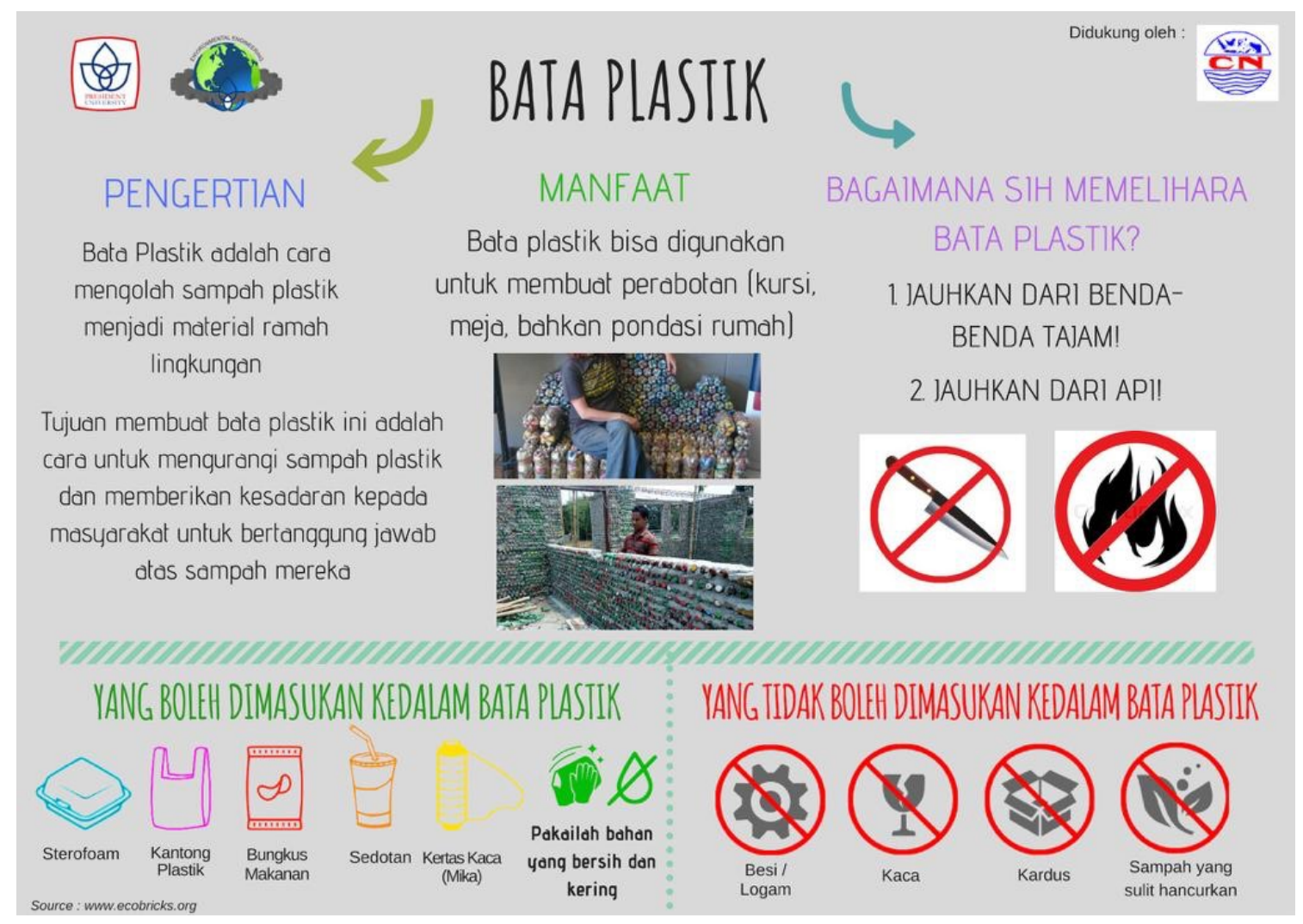

Gambar 11. Poster Materi Penyuluhan - Bata Plastik / Eco-brick

Selain mendaur ulang sampah plastik, sampah plastik jenis PE, PP, dan PVC dapat dikonversi menjadi bahan bakar minyak (Surono, 2013). Hal ini sangat bagus dsalam upaya mengurangi sampah plastik, selain itu juga dalam mengurangi eksploitasi minyak bumi.

\section{KESIMPULAN}

Kegiatan pendidikan lingkungan ini perlu terus dilakukan dan ditingkatkan agar kesadaran dan kepedulian akan sampah plastik ini meningkat di tengah masyarakat Indonesia, khususnya Jawa Barat Tingkat kesadaran lingkungan ini tidak berbanding lurus dengan tingkat ekonomi, tingkat pendidikan, ataupun latar belakang profil lainnya. Hal ini menuntut upaya yang terus-menerus dan meningkat dilakukan agar memberikan dampak pada perubahan perilaku bermasyarakat.

Dibutuhkan banyak agen perubahan yang terus bergerak menginisiasi dan menciptakan komunitas-komunitas peduli lingkungan yang memiliki program kerja dan kegiatan yang berkelanjutan. Mahasiswa Universitas Presiden memiliki peran yang penting dalam kegiatan pengabdian kepada masyarakat ini. Wawasan, semangat, dan teladan yang baik dapat mereka berikan dan inilah yang menjadikan Universitas Presiden memiliki nama yang baik karena telah bermanfaat bagi lingkungan sekitarnya. 


\section{UCAPAN TERIMA KASIH}

Dalam kesempatan ini penghargaan dan rasa terimakasih disampaikan kepada LRPM Universitas Presiden yang telah mendanai kegiatan pengabdian masyarakat ini. Kegiatan pengabdian masyarakat ini merupakan upaya yang harus dilakukan secara berkesinambungan mengingat dampak dari aktifitas pengabdian ini seharusnya dapat meningkatkan kesadaran dan pengetahuan masyarakat terhadap sampah plastik dan mendorong penggunaan yang bijak dan bertanggungjawab. Ucapan terima kasih penulis sampaikan khusus kepada mahasiswa Teknik Lingkungan 2016 yang mengelola kegiatan pengabdian masyarakat ini dengan sangat baik. Terimakasih juga kami ucapkan bagi seluruh dosen dan mahasiswa Teknik Lingkungan yang terlibat dalam kegiatan pengabdian masyarakat ini.

\section{REFERENSI}

Abella, T. A. (2013). Follow the Rs: Reduce, Replace, Reuse, Recycle, Recover, Refuse and Reject, Rethink. Envirocities E-magazine.

Browne, M.A., Crump, P., Niven, S.J., Teuten, E.,Tonkin, A., Galloway, T., Thompson, R., (2011). Accumulation of microplastic on shorelines worldwide: sources and sinks. Environ. Sci.Technol., 45(21): 9175-917.

DKN (Dewan Ketahanan Nasional). (2018). Materi Presentasi yang dibawakan oleh Sesjen Wantanas-Dewan Ketahanan Nasional dan Narasumber lainnya. Diunduh dari: https://www.dkn.go.id/berita/197/sesjen-wantannas-menjadi-keynote-speakerpada-acara--diskusi-panel-di-universitas-parahyangan.html https://unpar.ac.id/membingkai-keterlibatan-lembaga-pendidikan-tinggi-dalamrestorasi-sungai-citarum/

http://perpustakaan.bappenas.go.id/lontar/file?file=digital/95110$\% 5 B \_K o n t e n \_\% 5 D-K e t a h a n a n \% 20 P a n g a n . p d f$

https://www.dkn.go.id/berita/169/sesjen-wantannas-diskusikan-citarum-harumbersama-menko-maritim.html

Ismail, Yunita and Sidjabat M. Filson. (2019). Community Empowerment in Household Waste Management. Journal of Community Engagement, 1(1): 24-29.

J. R. Jambeck, R. Geyer, C. Wilcox, T. R. Siegler, M. Perryman, A. Andrady, R. Narayan, K. L. Law. (2015). Plastic waste inputs from land into the ocean. Science, 347(6223): 768-771.

Kim, Ji-Su et al. (2018). Global Pattern of Microplastics (MPs) in Commercial Food-Grade Salts: Sea Salt as an Indicator of Seawater MP Pollution. Environmental Science \& Technology. DOI: 10.1021.

Kurniadi, H., dan Hizasalasi, M. (2017). Strategi komunikasi dalam kampanye diet kantong plastik oleh GIDKP di Indonesia. Jurnal Medium, 6(1): 1-11. 
Sedayu, B. B. (2018). Perut paus sperma penuh plastik di Wakatobi: lima langkah kurangi ancaman mikroplastik di laut Indonesia. Diunduh dari http://theconversation.com/perut-paus-sperma-penuh-plastik-di-wakatobi-limalangkah-kurangi-ancaman-mikroplastik-di-laut-indonesia-104484

Surono, U. B. (2013). Berbagai metode konversi sampah plastik menjadi bahan bakar minyak. Jurnal Teknik, 3(1): 32-40.

Widyaningrum, G. L. (2018). Perilaku Manusia dan Dampak Sampah Plastik yang Menewaskan Hewan Laut. Diunduh dari http://nationalgeographic.grid.id/read/131244353/perilaku-manusia-dan-dampaksampah-plastik-yang-menewaskan-hewan-laut?page=all 